\title{
Trade-Related Environmental Measures under the World Trade Organization (WTO) in Malaysia: The Analysis of its' Application
}

\author{
${ }^{1}$ Yanti Ahmad Shafiee \& ${ }^{2}$ Asmah Laili Yeon \\ ${ }^{1}$ Labuan Faculty of International Finance \\ Universiti Malaysia Sabah, Labuan International Campus \\ W.P. Labuan \\ ${ }^{2}$ School of Law, College of Law, Government and International Studies \\ Universiti Utara Malaysia \\ ${ }^{1}$ Corresponding author: y.tie@hotmail.com; \\ asmah485@uum.edu.my \\ DOI: https://doi.org/10.32890/jis2016.12.7
}

Abstract

The objective of this study is to explore the application of trade-related environmental measures in Malaysia. Trade-related environmental measures are environmental measures that were invoked which may have an effect on international trade. These measures can be in the form of tariff and non- tariff. As a member of the World Trade Organization (WTO), Malaysia is compelled to apply and implement the environmental provisions of the General Agreement of Tariff and Trade (GATT) and the WTO agreements. However, the ability to fully comply with these agreements needs to be determined as Malaysia's effort in environmental protection could affect its international trading. In this study the analysis was on Malaysia's domestic legislations; the GATT, especially Article XX; WTO agreements such as the Agreement on the Application of Sanitary and Phytosanitary Measures (SPS), the Agreement on Technical Barriers to Trade (TBT) and the WTO Dispute Settlement Body decided cases. Secondary data such as journal articles were referred. It is expected that this study could assist in determining the efforts made by Malaysia in finding a balance between international trade and environmental protection.

Keywords: International Economic Law, International Trade, Environmental Protection, Trade-Related Environmental Measures, Malaysia.

\section{Introduction}

The relationship between development and environmental protection has been examined since the 1970s. The United Nations has held two major conferences on. The first one was the 1972 United Nations Conference on Human Environment (UNCHE) which adopted the Stockholm Declaration. The second was the United Nations Conference on Environment and Development in 1992. This conference adopted the Rio Declaration and this was the first step taken by the global community to explore the means for environmental protection 
in view of development (Gardiner, 2003). The element of integration between environment and development was recognized in this declaration and it represented the commitment of developed and developing countries in maintaining the balance between environmental protection and economic development.

With respect to international trade, the authorities that need to look into the effect of environmental protection are the 1994 General Agreement on Tariff and Trade (GATT) and the World Trade Organization (WTO) agreements. The preamble of the Marrakesh Agreement Establishing the World Trade Organization (WTO) states that:

\begin{abstract}
"Recognizing that their relations in the field of trade and economic endeavour should be conducted with a view to raising standards of living, ensuring full employment and a large and steadily growing volume of real income and effective demand, and expanding the production of and trade in goods and services, while allowing for the optimal use of the world's resources in accordance with the objective of sustainable development, seeking both to protect and preserve the environment and to enhance the means for doing so in a manner consistent with their respective needs and concerns at different levels of economic development..."
\end{abstract}

From this preamble, we can understand that the WTO objective is not only to avoid discrimination in international trading but also to pursue sustainable development. One of the efforts that the World Trade Organization (WTO) took was to set up the Committee of Trade and Environment (CTE) in 1994 to monitor the relationship of trade and environment in international trade. The Marrakesh Ministerial Decision on Trade and Environment (Marrakesh Decision) of 1994 identified 10 items as terms of reference for the CTE. The 10 items included the WTO and the Multilateral Environmental Agreements (MEA) relationship, environmental policies, market access and the effect of trade liberalization on the environment. Although the protection of the environment is not an objective of the WTO, the institution had instilled environmental provisions in order to control the effect of environmental measures taken out by member states on international trading (Shih, 2006).

\title{
Trade-related Environmental Measure as a Trade Barrier
}

The meaning of environment differs politically and scientifically and varies according to different multilateral trade agreements and conferences. The 1972 Stockholm Declaration refers to "air, water, land, flora and fauna" as natural resources. Article XX paragraph (b) and (g) of the General Agreement of Tariff and Trade (GATT) mentioned "human, animal, plant life or health and exhaustible resources" but did not state the word "environment" per se (Sands, 2003). As the study is about to the provisions of the WTO, the meaning of environment comprises of what the WTO refers to as human, animal, plant life and health. Furthermore, the WTO agreement itself is not concerned with air pollution and nature. 
According to Birnie, Boyle, \& Redgwell (2010) the types of measures taken out in view of environmental protection are trade restrictions to protect resources beyond national jurisdiction and trade restrictions to protect the domestic environment. A country which needs to protect its domestic environment would carry out three (3) kinds of trade restrictions. These restrictions are import restrictions on products and services which do not comply with the domestic regulations, requirement that both local and imported products are to comply with regulations on matters such as labelling, packaging and recycling, and restrictions on export product in order to conserve natural resources.

These trade restrictions are usually aimed at product standards and production standards. Product standards refer to the characteristics that goods must possess, such as performance requirements, minimum nutrient content and maximum toxicity or noxious emissions. Production standards on the other hand refer to conditions under which products are made (Khatun, 2009).

Trade restrictions can be non-tariff and tariff barriers. Non-tariff barriers, created more problems to developing countries' exporters than developed countries' exporters. The types of non-tariff barriers invoked depend on each country is requirements and concerns. According to Islam et al. (2010) non-tariff barriers to trade could be specific limitations on trade such as quantitative restrictions, export restraints, health and sanitary regulations, licensing, embargoes and minimum price regulations; standards such as industrial standards, packaging, labelling and marking regulations; and customs and administrative entry procedures such as customs valuation, customs classification, antidumping duties, consular and customs formalities and requirements, and sample requirements. Developed countries would apply trade restrictions against developing or least developed countries if they find that these countries produced goods that would threaten their domestic environment and thus, developing countries need to deal with these restrictions.

\section{Trade- related Environmental Measures Under the World Trade Organization (WTO)}

The environmental protection mechanism instilled under the WTO are Article XX paragraphs (b) and (g) of the General Agreement of Tariff and Trade (GATT), Agreement on the Application of Sanitary and Phytosanitary Measures (SPS) and the Agreement on Technical Barriers to Trade (TBT) (Shih, 2006).

The preamble of the Agreement on the Application of Sanitary and Phytosanitary Measures (SPS) states:

" No member should be prevented from adopting or enforcing measures necessary to protect human, animal or plant life or health, subject to the requirement that these measures are not applied in a manner which would constitute a means of arbitrary or unjustifiable discrimination between members where the same conditions prevail or a disguised restriction on international trade." 
The SPS Agreement allows members to take out measures that could protect human, animal or plant life or health but then such measures cannot discriminate between members and they are not a disguised restriction to trade. A member that imposed an SPS measure should prove that the standard of measure is high and that they have strong scientific evidence to prove that the measure is necessary.

This Agreement allows Members to take out measures in order to protect human, animal or plant life or health. However, members have to show that the standard of measure which has been invoked is high and that they have strong scientific evidence that the measure is necessary. Therefore under this agreement, members have the right to apply any measure as long as it is necessary and it should be maintained based on strong scientific evidence and again the measure must not be an ' unjustifiable discrimination between members where the same conditions prevail or a disguised restriction on international trade' (Cheyne, 2007). However, a member could pursue measure without having to provide scientific evidence as allowed by Article 3.3 and Article 5.7 of the SPS Agreement:

Article 3.3:

'Members may introduce or maintain sanitary or phytosanitary measures which result in a higher level of sanitary or phytosanitary protection than would be achieved by measures based on the relevant international standards, guidelines or recommendations, if there is a scientific justification, or as a consequence of the level of sanitary or phytosanitary protection a member determines to be appropriate in accordance with the relevant provisions of paragraphs 1 through 8 of Article 5'

Article 5.7:

'In cases where relevant scientific evidence is insufficient, a member may provisionally adopt sanitary or phytosanitary measure on the basis of available pertinent information, including that from the relevant international organization as well as from sanitary and phytosanitary measures applied by other members. In such circumstances, members shall seek to obtain the additional information necessary for a more objective assessment of risk and review the sanitary or phytosanitary measure accordingly within a reasonable period of time.'

A country often applies a precautionary approach whenever it could not produce sufficient evidence to justify its measure under the SPS Agreement and Article XX (b). The appellant Body recognized this provision in some of its decided cases and reflected it as a precautionary principle. There are elements of precautionary principle in Articles 3.3 and 5.7 of the SPS Agreement.

The Agreement on Technical Barrier to Trade (TBT), also states:

"No country should be prevented from taking measures necessary to ensure the quality of its exports, or for the protection of human, animal, or plant life 
or health, or the environment, or for the prevention of deceptive practices at the levels it considers appropriate, subject to the requirement that they are not applied in a manner which would constitute a means of arbitrary or unjustifiable discrimination between countries where the same conditions prevail or a disguised restriction on international trade, and are otherwise in accordance with the provisions of this Agreement".

The TBT Agreement requires technical regulations to be less restrictive even if they are discriminatory. This can be a non-discriminatory regulation which is reasonably available to a member in order to achieve regulatory goals for matters such as environmental protection, public health, consumer safety and welfare or financial security. A member, however, has to opt for a measure which will have the least trade restrictive consequences (Van Claster, 2008).

The TBT Agreement encourages the use of international standards by members in assessing their protection measures. Article 2.4 provides that members are to use such standards, 'except when such international standards or relevant parts would be ineffective or inappropriate means for the fulfillment of the legitimate objectives pursued.' Article 2.9 provides a notification procedure in respect of a technical regulation that 'may have a significant effect on the trade of other members in cases where a relevant international standard does not exist' or ' the technical content of the proposed regulation is not in accordance with the technical content of relevant international standards.'

Article 2.2 of the Agreement states that members cannot prepare, adopt or apply technical regulations' with a view to or with the effect of creating unnecessary obstacles to international trade'. Article 2.5 then provides that a technical regulation that is adopted in accordance with a legitimate objective and is based on international standard 'shall be rebuttable presuming not to create an unnecessary obstacle to international trade.'

Article XX of the General Agreement of Tariff and Trade (GATT) allows members to apply environmental protection measures if they could provide evidence or proof which could justify the exceptions under Article XX paragraph (b) and paragraph (g) of GATT. This Article provides that a member could take out an environmental measure that is necessary to protect human, animal or plant life or health (paragraph b) and the measure should be relating to the conservation of exhaustible natural resources and is taken out to restrict the production and consumption of that particular resource (paragraph $\mathrm{g}$ ). However these measures can only be taken out as long as it is not applied in a manner which would constitute a means of arbitrary or is unjustifiable discrimination between countries where the same condition prevails or disguised on international trade.

The WTO Dispute Settlement Panel is using a 'two step' test in order to decide whether an environmental measure carried out by a country could satisfy Article XX (b) and (g) and justify under its "chapeau". First, the measure must satisfy either exception (b) or (g) of the Article. Therefore, the measure should be found to be necessary to protect human, animal 
or plant life or health and that it relates to the conservation of exhaustible natural resources. The country which carried out the measure should show evidence that the measure was necessary. They must also provide evidence that their action was important to conserve exhaustible natural resources and that the resources are really exhaustible, for example, oil or even animals such as turtles.

After satisfying the exceptions in Article XX (b) and (g), then the Panel will decide whether the measure is discriminatory or not, and not a disguised restriction to international trade as required by the "chapeau" of Article XX. The WTO Panel succeeded in using this test in cases such as the Reformulated Gasoline, Shrimp/Turtle and Asbestos in distinguishing whether an environmental measure is a legitimate environmental protection or just a technical barrier to trade and an excuse for protectionism (Ghei, 2007).

The WTO environmental provisions will only be applied to environmental protection measures if such measures would affect international trading (Matsushita et al., 2006). Through the implementation of these provisions, the WTO is trying to ensure that environmental protection will not be a barrier to international trade and that any protection measures taken out by members are not discriminatory and thus, genuine. The WTO then has to differentiate between a legitimate environmental protection measure and a measure which is use as a disguised restriction to trade (Ghei, 2007). As it is, Malaysia has to comply with international laws with regards to international trading, particularly the World Trade Organization (WTO) agreements and the General Agreement of Tariff and Trade (GATT). Apart from these environmental provisions, there are international trade provisions which have an impact and could be affected by environmental protection measures with respect to the trading of goods. These provisions are Article I and Article III of GATT. Article I requires a member of the WTO not to discriminate products between member countries and that all type of products are to be treated equally. Article III disallows members to discriminate between imported and exported goods. Article I and Article III would affect environmental measures taken out by member states. For example, a member state could invoke an environmental measure which would contradict Article I of the GATT where such measure could discriminate between member states if not all the member states could comply with the measure due to financial or technical restraints.

The application of these international trade regulations in domestic law and its implementation has its challenges. As a member of the WTO, a country is compelled to carry out the terms which have been agreed upon. One of the ways to carry them out is by applying the terms of these agreements to domestic law. Through this, the country could then implement the terms accordingly (Ansari, 2007). For example, with respect to the application of environmental regulations, it was claimed that the ratification of multilateral environmental agreements depends on the constitutional requirements of a particular country as countries differ in terms of formulating and implementing the required legislation. It is perceived that the effectiveness in implementing environmental law is by effectively implementing them through the domestic environmental law. Environmental law and policy could only be 
carried out effectively if they have successfully been implemented domestically as different countries would require different solution to their environmental problems (Ansari, 2007).

\section{World Trade Organization's (WTO) Environmental Measures Dispute Cases}

The following cases demonstrate how domestic regulation can be a barrier to international trade and was claimed to be used as a means of protection for domestic producers. Malaysia was involved in an international trade dispute which went before the WTO Dispute Settlement Body (DSB). In the case of United States-Import Prohibition of Certain Shrimp and Shrimp products, which went before the WTO's Dispute Settlement Panel in 1997, India, Pakistan, Thailand and Malaysia filed a complaint against the United States for invoking an embargo on their export of shrimps and shrimp products. This embargo was pursuant to the United States' Section 609 of Public Law 101-162. The issue which the Dispute Settlement Panel had to decide was whether the United States is justified in using the environment measure and whether the ban on the imports of shrimp and shrimps products from these countries for the protection of sea turtles was necessary.

In April 1998, the Dispute Settlement Panel decided that Section 609 has violated Article XX of the General Agreement of Tariff and Trade (GATT) and that the import ban taken out by the United States on the shrimps and shrimp products from India, Pakistan, Thailand and Malaysia constituted an "unjustifiable discrimination" and was inconsistent with the WTO practice of multilateral trading system. The United States filed an appeal to the Appellate Body of the WTO which then analysed the decision made by the Dispute Settlement Panel. They agreed with the panel's decision that the United States had violated Article XX but did not agree with the panel's argument in that case.

The Appellate Body found that the panel was right when they decided that the United States' regulation was threatening the multilateral trading system but found that the panel did not examine whether the United States regulation was "unjustifiable" and "discriminatory" and whether it was not inconsistent to GATT Article XX (b) and (g). The United States believed that they could still maintain the ban and remedied only whatever regulations which were claimed to be unjustified by the Appellate Body. The Appellate Body however, agreed with the United States' arguments in that case and believed that the United States had made an effort in the implementation of the Appellate Body's decision by negotiating with the relevant countries concerning the ban. Malaysia's claim that an international agreement should be concluded with regards to the lifting of the ban that had been dismissed by the Appellate Body.

Malaysia's claim that an international agreement should be concluded with regards to the lifting of the ban had been dismissed by the Appellate Body. The Appellate Body held that any action of requiring exporting countries to comply or abide with certain policies or requirements of the importing countries by any of the WTO member does not make it inconsistent with the WTO obligation. The United States embargo was a process and 
production type of measure which hit at the method in which the shrimps and shrimps products were harvested. This type of measure could affect the multilateral trading gravely as it will restrict market access based on the "conservation policies" of other countries.

Further, in October 2000, Malaysia told the DSB that it considered the United States not to be in compliance with the decision which has been made and requested that the question be referred to a compliance panel pursuant to Article 21.5 of the Dispute Settlement Understanding. The DSB referred the question to the original panel which concluded that the United States was then in compliance with its obligation under the GATT and would continue to be so, "as long as the conditions stated in the findings of the Report, in particular the ongoing serious good faith efforts to reach a multilateral agreement, remain satisfied." (De La Fayette, 2002).

Despite of Malaysia's arguments, the Appellate Body agreed with the Compliance Panel argument stating that the United States measure was justified and was not a 'disguised restrictions to international trade'. The fact that the United States allowed the exporting countries to adopt conservation measure which was suitable to their own local circumstances, rendered it to be non-discriminatory. Furthermore, Article XX did not require the United States to enter into an agreement before invoking the measure. It was decided that the United States needed to only to continue their good faith effort to reach international consensus (De La Fayette, 2002).

In the case of Thailand- Restrictions on Importation of and Internal Taxes on Cigarettes it had invoked a measure that was challenged by the United States. The Dispute Settlement Panel decided in this case that cigarettes which were sold in Thailand by domestic manufactures were the same as cigarettes which were produced in USA although according to the Thailand government, their cigarettes had a lower health risk. Thailand is defence under Article XX (b) of GATT was rejected because their action in banning the imports of cigarettes from USA was discriminatory, and was decided as a means to protect their domestic cigarette manufacturers. The measure was also considered as unnecessary by the Panel (Ghei, 2007). The Thai government claimed that the cigarettes were not "like products" as their cigarettes had lower health risks. The Dispute Settlement Panel reported that the cigarettes which were sold in Thailand by domestic manufacturers were the same as the cigarettes which were produced in USA.

Further, in the case of Brazil-Measures Affecting Imports of Retreaded Tyres it had imposed a ban on the import of re-treaded tires claiming that those tires had a short lifespan and would turn into waste tires easily and quicker than new tires. Brazil claimed that their ban was important in protecting human health and was justified under Article XX paragraph (b). They amended this regulation in 2004, and exempting the import of tyres originated from MERCOSURS countries from the import ban in order to obey a decision made by the MERCOSURS arbitral tribunal. 
The complaints were taken out by the European Communities (EC). EC claimed that Brazil's import ban had breached Article XIII and Article XX of GATT. Brazil confessed that their action was in violation of Article XIII as they had imposed charges on the import but they believed that their action was justified under Article XX. The Dispute Settlement Panel considered that the risk to health was indeed justified under Article XX paragraph (b). EC appealed to the WTO Appellate Body claiming that the Panel did not apply a proper weighing and balancing of factors surrounding the measures which had been taken before deciding that the measure was necessary.

However, the Appellate Body agreed with the decision of the Panel. The Appellate Body decided that, in addition to other factors, an analysis to ensure whether a measure was necessary should also include the process of weighing and balancing of 'the contribution made by the measure to its intended objective, the importance of the objective and the impact of the measure on trade'. The Appellate Body agreed with the Panel that Brazil's measure contributed to its objective in protecting human health. After having made the said decision, the Appellate Body then applied the two-step test and went to consider whether the measure was justified under the "chapeau" of Article XX.

It decided that the measure was not justified under the "chapeau" of Article XX and that it was applied in a manner which "constitutes a means of arbitrary or unjustifiable discrimination between countries where the same condition prevailed or was a disguised restriction to trade". The fact that Brazil decided to import re-treaded tyres from MERCOSURS countries was a discrimination against other countries. This exemption clearly did not meet the objective of Brazil in reducing waste tyres in view of health protection. Therefore, Brazil's measure failed as it was not justified under Article XX of GATT.

It was believed that environmental measures that imposed different standards between domestic producers and foreign producers, and relied heavily on quantitative restrictions which effectively created a barrier to entry might be a measure which functioned as a barrier to trade. A strict environmental measure could also be deemed to be a technical barrier as found by the Dispute Settlement Panel in the United States'-Import Prohibition of Certain Shrimps and Shrimp products case.

In the United States'- Standards for Reformulated and Conventional Gasoline, Brazil and Venezuela complained to the WTO with regards to the United States Clean Air Act which they claimed to have breached Article III of GATT. This Act introduced two gasoline programs in order to limit pollution from gasoline combustion to the 1990 levels. The Act required that all gas sold in certain areas be "reformulated" and the 1990 baselines were heavily relied on by the domestic producer in order to comply with the Act. However, the rule did not provide any baseline for foreign producers. The Panel found that the Act was not justified under Article III. They found that the domestic and foreign gasoline were 'like products' and that the Act had treated the product differently. This case was also an example where environmental rules were used as protectionism in favour of the domestic producers 
and a technical barrier to trade. It was believed to have treated older and domestic producers better than new and foreign producers. This rule increased the cost for foreign producers who were asked to comply with higher standards.

\section{The Application of Trade-Related Environmental Measures in Malaysia}

Malaysia has trade policies and measures that are affecting the imports and exports of goods. However, it has to comply with international trade rules and apply them domestically. The country, as a member of the WTO, is bound to follow the WTO agreement and GATT 1948. It has carried out its obligation to WTO by introducing new laws, amending the old ones and incorporating WTO's provisions into them. Trade-related environmental measures in Malaysia consist of measures directly affecting imports, exports, and production and trade. As to measures in protecting the environment, Malaysia has put in place regulations to that effect. With regards to Malaysia is commitment to the TBT Agreement, the country has invoked the Standards of Malaysia Act 1996. The Act was introduced in order 'to make new provisions in the law relating to standards and for other matters connected therewith'. Section 2 of the Act defines standard as:

'A document approved by a recognized body that provides, for common and repeated use, rules, guidelines or characteristics for products or related processes and production methods, for which compliance is not mandatory ; and which may also include or deal exclusively with terminology, symbols, packaging, marking or labelling requirements as they apply to a product, process or production method'.

Standard specification means 'a specification that has been declared to be a standard specification pursuant to Section 15.' Section 15(1) states:

'The Minister may, by notification in the Gazette, declare any specification that has been adopted with or without modification, to be a standard specification or a provisional standard specification for the purposes of this Act, and may amend or withdraw any standard specification or provisional standard specification.'

Further, Section 22 (1) states:

'The Minister may make such regulations as may be expedient or necessary for carrying out the purposes of this Act.'

The country has also invoked the Customs Act 1967. Under the Customs (Prohibition of Imports) Order 1998, in exercising the powers conferred by the Customs Act 1967, the Minister has the power to prohibit certain goods specified in the Order, originating or manufactured wholly or mainly in, or consigned from, the countries specified in the Order. 
Certain goods originating from certain countries specified in the Order are allowed provided that those countries could produce import licenses. The list of imports that required import license can be found in the Customs (Prohibition of Import) Order 1998 Schedule 4 Part 1. For example, regarding milk products, the import from all countries need to be accompanied by an import permit issued by or on behalf of the Director General of the Veterinary Services under the Animal Ordinance 1953. The importation of plant products including peas, beans, cashew nuts, groundnut, maize, rice, sesame, wheat, spices, tapioca, sorghum and gunny sacks from countries such as Bangladesh, India, Pakistan, Sudan, Turkey, Thailand, Philippines, Burma, Indonesia, Morocco and Sri Lanka, should be accompanied by a phytosanitary certificate issued by the authorized official from the country of export specifying treatments as determined by the Director General of Agriculture as required under the Plant Quarantine Regulations 1981. Logs and wood in the rough imported from all countries (excluding Indonesia) should be accompanied by an import permit issued by or on behalf of the Director General of the Malaysian Timber Industry Board.

The Customs (Prohibition of Imports) Order 1998 contains four schedules of items that are subject to various levels of restrictions. The first schedule includes 14 prohibited items banned for religious, security, health and environmental reasons. The second schedule lists products requiring licences, mainly for health, sanitary, security, environmental protection or intellectual property reasons. Products include poultry and beef (which must come from facilities that have been approved as halal or acceptable to Muslim consumers) eggs, rice, sugar, cement clinker, fireworks, etc. The third schedule, covering items subject to temporary import restrictions to protect domestic industry includes milk, coffee, cereal flour, certain wires and cables, and some iron and steel products. The fourth schedule contains items that may be imported only after meeting specific criteria; these include animals, animal products, plants, plant products, cigarettes, soils, fertilizers of animal origin, bullet- proof vests, electrical apparatus, safety belts and imitation weapons. (WT/TPR/S/156).

The Customs (Prohibition of Exports) Order 1998, under the Customs Act 1967, sets out export control requirements in three schedules. The first schedule consists of items that are absolutely prohibited from being exported. For example, exports of turtle eggs are prohibited as are exports of rattan from Peninsular Malaysia. The second schedule comprises goods subject to export licensing. The third schedule consists of items that can be exported only after meeting certain criteria for the protection of wildlife, health, security, and antiquities. Further, export duties are generally imposed on commodities such as crude petroleum and palm oil. The purpose of Malaysia's export duties is to discourage the export of raw materials and the export of wildlife. For example, a 5\% export duty is levied on cockles (molluscs), live cattle, buffaloes, goats, and wild animals and birds for conservation purposes (WT/TPR/S/156).

As to measures affecting production and trade, Malaysia applies sanitary and phytosanitary (SPS) measures to trade in plants, forest products, food and animal, and seafood products. The SPS measures are implemented under the Plant Quarantine Act 1976 and the Rules of Plant Quarantine 1981; the Codex Alimentarius Commission and the International Plant 
Protection Convention (IPPC) aimed at protecting Malaysia's agriculture from foreign plant diseases, pets and infection. The Animal Ordinance 1953 aims primarily to prevent animal diseases and pests from infecting Malaysian livestock. It regulates the control and eradication of disease, animal conservation and welfare, export/import control and enforcement. The Fisheries Act 1953 covers the distribution and marketing of live fish and related organisms and the Food Act 1983 and Food Regulations 1985 cover the preparation, sale, and use of food (WT/TPR/S/156).

Under Malaysian food standards and regulations, domestic and imported food products must be processed, stored and handled in a sanitary manner. The authorities have worked to harmonize food standards with those applied internationally and have also contributed to the development of the Codex standards. Thus nutritional labelling requirements are imposed for certain food products, including cereals, breads, milk, various canned foods and fruit juices, soft drinks and salad dressings (WT/TPR/S/156).

The regulations which are enacted due to Malaysia's obligation under the SPS Agreement, with respect to handling of food and agricultural products, are the Plant Quarantine Act 1976, Plant Quarantine Regulations 1981, Animal Act 1953 (Revised 2006), Fisheries Act 1985, Food Act 1983 and Food Regulations 1985.

In the introduction of the Plant Quarantine Act 1976, it is stated that:-

\begin{abstract}
'An Act to amend and consolidate the laws relating to the control, prevention and eradication of agricultural pests, noxious plants and plant diseases and to extend co-operation in the control of the movement of pests in international trade and for matters connected therewith.'
\end{abstract}

The sanitary and phytosanitary measures can be found in Sections 6, 12, 14 and 19 of the Act. For example, Section 6 (1) states that if it appears to the Inspecting Officer that any plant is diseased and might endanger other plants, he may serve a notice to the owner or the occupier of the land wherever the plant is found and direct the owner or occupier to eradicate or destruct, remove the plant or treat the plant in the manner specified in the notice so as to prevent the spread of the pest. Section 6 (2) further states that if it appears to the Inspecting Officer that any land or plant is in a condition favourable to the introduction or spread of any pest, he may serve a notice to the owner or the occupier of the land directing the owner to eradicate or destruct, remove the plant or treat the plant in the manner specified in the said notice so as to prevent the spread of the pest.

Fisheries Act 1985 relates to 'fisheries, including the conservation, management and development of maritime and estuarine fishing and fisheries, in Malaysian fisheries water, to turtles and riverine fishing in Malaysia, and to matters connected therewith or incidental thereto; The sanitary and phytosanitary measures which are taken out by this Act are in Sections 6, 27, 40. Section 6 is about the preparation of the fisheries plan. It states that: 
'The director general shall prepare and keep under continual review fisheries plans based on the best scientific information available and designed to ensure optimum utilization of fishery resources, consistent with sound conservation and management principles and with avoidance of overfishing.'

Section 27(1) states:

'No person shall fish for, disturb, harass, catch or take any aquatic mammal or turtle which is found beyond the jurisdiction of any state in Malaysia.'

Section 40 is about the control of life fish and it states that any person who imports or exports out of Malaysia or transports those fishes within Malaysia without a permit or in breach of any condition in a permit issued by the Director General under this Section shall be guilty of an offence.

In the preamble of the Food Act 1983 it is described that this act is:

'An act to protect the public against health hazards and fraud in the preparation, sale and use of food and for matters incidental thereto or connected therewith'.

It described the administration and enforcement; offences and evidence, importation, warranty and offences of handling of food in Malaysia. The SPS measures are contained in Sections 9, 10, 13, 13B, 13C, 14, 15, 20, 21.

Apart from that, the Food Act 1983 describes the administration and enforcement; offences and evidence; importation, warranty and offences of handling of food in Malaysia. The regulations thus, are enforced by the Ministry of Health. Due to the commitment to WTO environmental provisions, an amendment was made to Regulation 43. The amendment was made with respect to adding new requirements on wheat flour. A new regulation, namely Regulation 43A was also added with respect to the requirements on bread flour. These amendments referred respect to texture and flours. Other amendments were made with respect to Regulations 44, 45, 46 and 47.

The Malaysian government also needs to give notification to all its trading partners with respect to all its trade-related environmental protection provisions. For example, one of the new plant protection provisions is the implementation of a new import requirement for fresh mangosteens into Malaysia. Notification on the new import requirement for fresh mangosteen from all countries was dated 30th March 2015. The new import requirement was implemented from 1st of July 2015 with a grace period of four months until 31st October 2015. The full implementation commenced from 1st November 2015. This information is also a notice to domestic stakeholders (https://docs.wto.org/dol2fe/Pages/FE_S_S009-DP. aspx). 
Further, the Malaysian Standards Industrial Research Institute Malaysia (SIRIM) is the organization designated as a national enquiry point for technical barriers to trade (TBT) in the World Trade Organization (WTO). In 2003, it informed the local manufacturers that the Ministry of Social Welfare of Colombia had proposed a new requirement for the labelling of natural latex condoms. A local company voiced its objection against such a requirement. The company was then asked to put up a case for it to be discussed at the National SubCommittee (NSC) on the TBT Agreement. The NSC consists of representatives of the Ministries for Trade, Industry, Consumer Affairs, Health, Agriculture and Science, other regulatory agencies, national trade and industry associations, and SIRIM as the secretariat. The NSC examines and formulates responses to WTO notifications. After deliberating the case, a response was formulated in which the requirements made by Columbia should be reasonably followed (https://www.wto.org/english/res_e/booksp_e/case24_e.htm).

Despite Malaysia's massive role in implementing the international trade law with respect to environmental protection, the country has also faced some issues regarding this matter. With respect to the Malaysian timber trade, non- tariff barriers were used to restrict either the import or export of timber. This caused difficulties to timber production. It was perceived that the containing of non-tariff barriers could create less difficulties for certain timber products in certain markets (Islam et al., 2010). The EU demanded certification for timber sourced from a forest that is sustainably managed. Therefore, the preference for certain specification schemes discriminates timber which is certified under the national scheme such as in the Malaysian Timber Certification Council (MTCC) scheme. The effect of trade barriers on timber trade is to restrict the ability of the developing countries to produce more processed products which provide the opportunity for increased economic and social development.

\section{Conclusion}

As a member of the WTO, Malaysia has complied with the WTO laws by applying the laws under its domestic regulations. Malaysia also has tried to comply with the environmental measures taken out by other states and sacrificed its trade for the sake of environmental protection. However, much more efforts need to be done. For example, in the case of the United States-Import Prohibition of Certain Shrimp and Shrimp products, Malaysia has to adhere to the decision of the Panel where it was decided that Article XX did not require the United States to conclude an international agreement before imposing its unilateral measure and that the exporting states only need to adopt a conservation program that suited their local environment which could preserve the product concerned.

Although, WTO is more concerned about encouraging its members to enter into multilateral agreements, the fact the United States had entered into and continues good faith efforts to reach international consensus by setting up an MOU to protect sea turtles in the Indian Ocean and the South East Asian region confirmed by the Appellate Body is a sufficient effort. Through these agreements, disputes could be avoided and international trade will not 
be affected. However, the WTO should not dismiss the fact that developing countries need assistance in carrying out these trade-related environmental measures.

Developing countries comprise two-thirds of the WTO membership and they have brought much attention to the issue of trade and development in the WTO (Lee, 2006). With respect to WTO laws, developing countries should be given flexibility to implement WTO rules considering their economic condition. This act would result in the rebalancing the rights and obligations of WTO members. But it should only be in the circumstances where this measure will contribute to the developing countries' needs and there is no reasonable alternative less trade restrictive measure available (Chang, 2007).

Regulating and enforcing domestic and international rules with regards to environmental protection have been a big challenge to developing countries since they rely heavily on free trade. In view of this, they will also have problems in enforcing domestic or regional trade rules. Today, the trade and environmental issues in terms of environmental protection and the regulatory impact of trade rules remain unsettled. Sands (2003) claims that the environment will affect development and international trading when certain countries or organizations started to set up measures and standards in order to protect the environment. Even the terms and conditions in some of the multilateral environmental agreements (MEA) entered into by member countries of the WTO are conflicting with WTO's concept of trade liberalization (Ben Boer et al., 1998).

Developing countries should be given more flexibilities to implement WTO rules and this in turn could result in rebalancing the rights and obligations of WTO members. This could be done if the policy measure at issue can contribute to the particular developing country's development needs in a situation where there is no alternative less trade restrictive measure available (Carrapatoso, 2009). Under the Malaysian trade policy, various non-tariff trade measures are used as instruments to restrict goods (Al-Amin et al., 2008). Malaysia then, should put in place good trade rules that would take into account the effect of trade on the environment in order that trade activities will not affect environment protection extensively and vice versa.

\section{References}

Al Amin, Chamhuri Siwar, Hurul Huda, \& Abdul Hamid. (2009). Trade, economic development and environment: Malaysian experience. The Bangladesh Development Studies, 19-39.

Ansari, A. (2007). GATT/WTO and MEA's: Resolving the competing paradigm. Journal of International Trade Law and Policy, 2-13.

Birnie, P., Boyle, A., \& Redgwell, C. (2009). International law and the environment. New York: Oxford University Press.

Boer, B., Ramsay, R., \& Rothwell, D. (1998). International environmental law in the Asia Pacific. London: Kluwer Law International. 
${ }^{1}$ Yanti Ahmad Shafiee \& ${ }^{2}$ Asmah Laili Yeon

Brazil-measures affecting imports of retreaded tyres, WT/DS332/R (Dispute Settlement Body June 12, 2007).

Carrapatoso, A. F. (2008). Environment aspects in free trade agreements in the Asia Pacific region. AEJ, 229-243.

Chang, S. W. (2007). WTO for trade and development post- Doha. Journal of International Economic Law, 553-570.

Charnovitz, S. (2007). Trade and the environment in the WTO. Journal of International Economic Law, 1-29.

Cheyne, I. (2007). Gateways to the precautionary principle in WTO Law. Journal of Environmental Law, 155-172.

De La Fayette, L. (2002). United States- Import prohibition of certain shrimp and shrimp products- Recourse to Article 21.5 of the DSU by Malaysia. 96 American Journal of International Law , 685-692.

Gardiner, R. K. (2003). International Law. New York: Oxford University Press.

Ghei, N. (2007). Evaluating the WTO's two step test for environmental measures under article XX. Colorado Journal of International Environmental Law \& Policy, 117-150.

Islam, R., Siwar, C., Mohamad Ismail, S., \& Bhuiyan, A. (2010). Impacts on trade barriers to timber trade in Malaysia. World Journal of Management, 13-21.

Khatun, F. (2009). Environmental related trade barriers and the WTO. Regional Conference on Trade, WTO and Sustainable Development: A Cause of Concern (pp. 1-17). Kuala Lumpur: Centre for Policy Dialogue.

Lee, Y. (2006). Facilitating development in the World Trade Organization: A proposal for the council for trade and development and the agreement on development facilitation. Asper Review International Business \& Trade Law, 177.

Managing the challenges of WTO participation: Case study. (2015, July 31). Retrieved from World Trade Organization: https://www.wto.org/english/res_e/booksp_e/ casestudies_e/case24_e.html

Matsushita, M., Schoenbaum, T., \& Mavroidis, P. (2006). The World Trade Organization law, practice and policy. New York: Oxford University Pres.

Sands, P. (2003). Principles of international environmental law. United Kingdom: Cambridge University Press.

Shih, W. C. (2006). Trade and environmental linkages and challenges facing East Asian WTO members. Asian Journal WTO \& International Health Law and Policy, 157-188.

Thailand- restrictionson importation of and internal taxes on cigarettes, BISD37S/200 (GATT Panel November 7, 1990).

Trade policies and practices by measure- Malaysia, WT/TPR/S/156.

United States- import of certain shrimp and shrimp products, WT/DS58/ABR (WTO Panel Reports November 1998, 1998).

United States- standards for reformulated and conventional gasoline, WT/DS2/AB/R (WTO Appellate Body May 20, 1996).

Van Calster. (2008). Faites Vos Jeux- regulatory autonomy and the World Trade Organization after Brazil Tyres. Journal of Environmental Law, 121-136.

World Trade Organization Documents. (2015, December 31). Retrieved from World Trade Organization: https://docs.wto.org/dol2fe/Pages/FE_Search/FE_S_S009-Html.aspx 